ENTREPRENEURSHIP AND SUSTAINABILITY ISSUES

ISSN 2345-0282 (online) http://jssidoi.org/jesi/

2019 Volume 6 Number 3 (March)

http://doi.org/10.9770/jesi.2019.6.3(15)

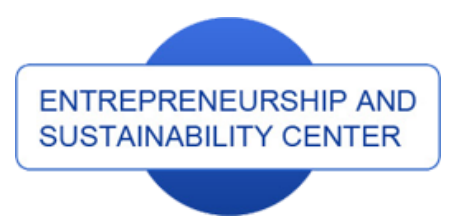

Publisher

http://jssidoi.org/esc/home

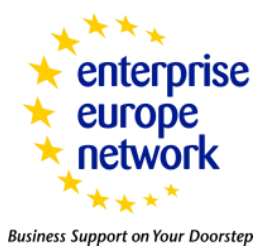

CASPA

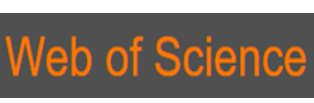

1) Clarivate

\title{
SECURITY POSITION AND DETECTION OF UNUSUAL BUSINESS OPERATIONS FROM SCIENCE AND RESEARCH PERSPECTIVE
}

\author{
Antonín Korauš ${ }^{1}$, Ján Dobrovič², Jozef Polák ${ }^{3}$, Pavel Kelemen ${ }^{4}$ \\ ${ }^{1}$ Academy of the Police Force in Bratislava, Sklabinská 1, 83517 Bratislava 35, Slovak Republic \\ 2,3,4 University of Prešov in Prešov, Faculty of Management, Konštantínova 16, 08001 Prešov, Slovak Republic \\ E-mails: ${ }^{1}$ antonin.koraus@minv.sk, ${ }^{2}$ jan.dobrovic@unipo.sk, ${ }^{3}$ jozefpolak64@gmail.com,${ }^{4}$ kelemen.pavel@gmail.com
}

Received 11 Seprember 2018; accepted 18 January 2019; published 30 March 2019

\begin{abstract}
Security aspects and detection of unusual business operations (UBO) is a continuation of the ever-increasing need to assure priorities in research and development, particularly in ICT, for all key scientific research institutions in the critical services sector in the European Economic Area. This creates a complex ecosystem of continuous research and innovation. Maintaining this continuity is critical for introducing innovations to meet the legal and security frameworks in the context of the ever-expanding financial market and economic growth that the European Union countries are committed to by important documents such as Directive 2005/60 / EC of the European Parliament and Council from 26 October 2005, Commission Directive 2006/70 / EC from 1 August 2006, national laws on protection against the legalization of proceeds of crime (in the Slovak Republic, this is Act 297/2008 Coll. of 2 July 2008 on protection against the legalization of proceeds of crime and protection against terrorist financing, including amendments supplements to certain laws), and protection against terrorist financing, as well as laws on the implementation of international sanctions. These legal frameworks represent high costs for the entire sector (e.g. obligated persons), especially in the implementation of automated procedures in the evaluation of unusual business operations amounting to more than EUR 3 billion only in the Slovak environment. In accordance with the abovementioned legal regulation, the obligated person (duty to report UBOs) becomes anyone who carries out a non-standard financial operation.
\end{abstract}

Keywords: security, unusual business operations, crime, money laundering, corruption, legal acts

Reference to this paper should be made as follows: Korauš, A.; Dobrovič, J.; Polák, J.; Kelemen, P. 2019. Security position and detection of unusual business operations from science and research perspective, Entrepreneurship and Sustainability Issues 6(3):1270-1279. http://doi.org/10.9770/jesi.2019.6.3(15)

JEL Classifications: E26, E42, G21 


\section{ENTREPRENEURSHIP AND SUSTAINABILITY ISSUES}

ISSN 2345-0282 (online) http://jssidoi.org/jesi/

2019 Volume 6 Number 3 (March)

http://doi.org/10.9770/jesi.2019.6.3(15)

\section{Introduction}

The topic of security and detection of unusual business operations is extremely topical not only from the point of view of the Slovak Republic, but also from that of the European Union as well as from the global point of view. In accordance with Act No. 297/2008 Coll. of 2 July 2008 on the Protection against the Legalization of Proceeds of Crime and Financing of Terrorism including amendments to certain acts, an unusual business operation is defined to encompass legal acts or other acts implying that their execution may result in legalizing the proceeds of crime or financing the terrorism.

\section{Legalization of Proceeds of Crime ("Money Laundering")}

Money laundering is a dangerous international criminal activity that includes not only the activities of the underworld, but also the politicians or governments of some states (Jančíková, E., Pásztorová, J. 2018). Legalization of proceeds of crime ("money laundering") is a global problem with serious economic and social consequences. Financial institutions spend a significant amount of their resources on automated transaction tracking information systems (Mura et al., 2017; Durkalić, D. 2016; Lorincová, 2018) while their experience suggests that institutions are increasingly dissatisfied with their current automated tracking efforts, i.e. they are looking for software that can reduce the burden imposed on regulatory sections (compliance). Some of these systems are implemented quickly, in a so-called "out of the box" manner in order to satisfy regulators, and later they are calibrated to detect significant suspicious activities.

Information technology in combination with advanced computing, particularly in form of data mining for the purpose of identification of money laundering and sophisticated detection of non-standard financial flows becomes important in combating money laundering as a specific part of legalization of proceeds of crime. From the point of view of institutions investigating the fight against money laundering, the financial and state institutions were predominantly active in the past (Gródek-Szostak; Nesterak, 2017). Following the tightening of legislation and intensification of the fight against money laundering and terrorism in recent years, universities are gradually joining this initiative.

The development of a new generation of systems which will have to meet future regulatory requirements as well as financial sector standards requires an interdisciplinary access and higher sophistication of information technologies. Slovakia is lagging behind in research and development on the issue of money laundering. Academic research and development are virtually absent in this area.

Corruption and money laundering are internally interconnected. Corruption offenses, such as theft of public funds, are generally linked to the purpose of own enrichment and acquisition of profits. Money laundering is a process of concealing illegal profits generated by crime. Successful legalization of revenue originating from the crime of corruption can minimize the fear of illegal profit confiscation.

The topic of money laundering is also a UN agenda, namely one of its components - United Nations Office on Drugs and Crime (UNODC). The OECD's activities in the area of tax criminal activity and money laundering complement the measures taken by FATF. These activities are carried out in a variety of ways, such as typological exercises, preparation and dissemination of practical instructions for detecting money laundering for central tax offices, tax advisers and auditors, exploration of key risk areas and coordination of OECD countries practices for sharing information against money laundering. One of the important materials be found in OECD recommendations to facilitate cooperation between legal and tax authorities promoting co-ordination of the fight against serious criminal activity. 


\section{ENTREPRENEURSHIP AND SUSTAINABILITY ISSUES}

ISSN 2345-0282 (online) http://jssidoi.org/jesi/

2019 Volume 6 Number 3 (March)

http://doi.org/10.9770/jesi.2019.6.3(15)

The Financial Action Task Force (FATF) sets standards for the development and support of national and international anti-money laundering and terrorist financing policies. Recommendations published by FATF are designed to effectively combat money laundering and terrorist financing while countering corruption. These measures are focused particularly on:

- Preserving the integrity of public sector,

- Protecting designated institutions in private sector from abuse,

- Increasing the transparency of financial system,

- Facilitating the detection, investigation and prosecution of corruption and money laundering and recovery of stolen assets.

The introduction of a coordinated procedure that is in line with anti-money laundering legalization standards creates an environment in which corruption is promoted in a much more difficult way, particularly an environment that does not ensure impunity.

At present, we can see a change in crime scene as well as in the composition of crime. In addition to classical forms of crime, new forms of crime committed by organized criminal groups are appearing at the forefront. Criminal activity is committed in a planned manner with a focus on long-term high profit, while measures against its detection are being implemented. New forms of crime focused on long-standing high profitability and application of often sophisticated anti-detection measures are increasingly common on an international scale.

In the hands of organized groups, which are increasingly frequently committing criminal activity on an international scale, huge sums of unlawfully gained income are received. The vast amount of profit thus obtained brings about the necessary need to transform it into a legal financial system and invest it in profitable economic unions or otherwise capitalize it.

In most cases, the commercial and financial transactions that introduce "dirty money" into the legal financial system are not very noticeable and almost do not differ from normal operations. Today, a wide range of products and services make it easier to introduce resources into the system. The use of ICT in international banking and financial and payment systems facilitates activities, but brings about a directly proportional increase in the risk of global money laundering and financing of terrorism. Cybersecurity issues in rather frequently is perceived as synonymous of security of critical infrastructure (e.g. Dobrovič et al. 2017; Veselovská et al. 2017; Korauš, Kelemen 2018; Šišulák 2017; Limba, Šidlauskas 2018).

\section{Results of Science and Research}

In order to effectively combat the introduction of criminal proceeds into the legal financial system, it is necessary to develop scientific methods that serve as the basis for creating software for systematic detection of unusual business operations. Quantitative systematic risk assessment methods are preferred such as RM/RA CRAMM (Mullerova 2016, Mamojka, Mullerova 2016, Palková 2018) to be combined with crime forecast maps (Mullerova, Mamojka 2017). Systematic detection of UBO is dependent upon the development and introduction of new software based on scientific methods.

Contributions from money laundering can be divided into two parts. They are scientific and professional. The latter describes the implementation of recommendations for handling unusual business operations. Money laundering is a relatively new area in terms of research (quarter of century). For this reason, there is room for discovering new trends based on experience in jurisdiction as well as detection methods. Primary areas of possible algorithm application are as follows: 


\section{ENTREPRENEURSHIP AND SUSTAINABILITY ISSUES}

ISSN 2345-0282 (online) http://jssidoi.org/jesi/

2019 Volume 6 Number 3 (March)

http://doi.org/10.9770/jesi.2019.6.3(15)

\section{Financial Operations}

To divert attention from too large sums, deposits are divided into small parts (so-called smurfing). Revenues from illicit trafficking are legalized through repeated deposits into accounts of various insiders in different countries and subsequent transfers to the destination country for the purpose of financing seemingly legal activities such as construction companies or pharmacies through the money-laundering process. The criminal organization will create a real labyrinth of mother and daughter companies with mutual ownerships and partnerships with headquarters in different countries, also subject to different tax regimes, the purpose of which is often not to achieve real profits, (if so, only indirectly), but to launder money generated by criminal activity.

\section{System of Insurance}

Many jurisdictions give the insured person the right to withdraw from insurance contract. This law is applicable within a certain period of time after the conclusion of contract, in principle without penalty and obligation to give reason for the withdrawal (as for the European Union, see Article 6 of Directive 2002/65 / EC). It is possible to conclude an insurance contract by single payment of premium by means of bank transfer, even from abroad, and then within a certain time limit to withdraw from the contract and claim back the amount paid. Since this amount formally comes from insurance, its illicit origin is easily hidden. Prior to this, the dirty money is invested in purchasing vehicles or other property, which is subsequently insured against theft or damage.

\section{Real Estate Market}

In case of money laundering, the real estate is purchased for a sum lower than its real value. The difference is paid in cash and this property is sold immediately, thus creating a fictitious capital gain that legalizes the income.

\section{Accounting - Auditing}

Issuing invoices for fictitious services or services below the declared value allows the company to justify and thereby legalize the amounts it has in its bank accounts. For the purpose of money pre-laundering, bank deposits are executed through fictitious companies or business activities (so-called front companies) directly or indirectly related to a criminal organization. The fictitious companies have cash availability due to their activities (restaurants, cinemas, supermarkets, gambling, etc.). In this way, legal proceeds and proceeds of crime are mixed and the recognition of injected amounts becomes almost impossible.

\section{Stock Exchanges}

Stellage is a market-based agreement whereby the buyer, after paying the insurance premium, reserves the right to decide whether to sell (so-called put options) or buy (so-called call options) a certain amount of bills and notes for a predetermined price and at a predetermined time. The stellage contract is then redeemed. Even if the person (Žul'ová et al., 2018) who is laundering the dirty money has to conclude the transaction with a mild loss at the maturity date, the amount received as a counter value for transferring the stellage is still formally covered by the option market operator and thus the connection with the crime is lost by means of investment. Swaps are yet another type of instrument. Swap is a derivative financial instrument that consists of regular cash flow exchanges between two counterparties. This agreement may be based on an exchange of interest rates or currencies. Swap transactions of repetitive and circular nature (in case of exchange between $\mathrm{A}$ and $\mathrm{B}$, followed by exchange between $\mathrm{B}$ and $\mathrm{C}$ and finally between $\mathrm{C}$ and $\mathrm{A}$ ) with a final zero balance can easily conceal the illegal origin of capital.

The degree of scientific contributions to money laundering and therefore unusual business operations varies. The best ones are published in journals indexed in the Web of Science database. There are not many of them. The reason for this is that many remain not published either because the algorithms and procedures are patented, or for tactical reasons on the grounds that the disclosure of the detection of unusual business operations to the public is undesirable. Rather, these contributions deal with the development in science-based areas as such, namely with the possibility of their application in the field of detection of legalization of criminal proceeds. 


\section{ENTREPRENEURSHIP AND SUSTAINABILITY ISSUES}

ISSN 2345-0282 (online) http://jssidoi.org/jesi/

2019 Volume 6 Number 3 (March)

http://doi.org/10.9770/jesi.2019.6.3(15)

With regards to the content, the posts can also be divided into two types. The first part consists of contributions where the methodology of money laundering research includes in most cases a combination of literature and secondary data. There are very few cases of empirical research into the phenomenon of money laundering or control thereof. Contributions use theory as a basis for research and as a support tool for analyzing and creating conclusions. Studies have an analytical, often descriptive character. The second part consists of contributions where the methodology consists of a description of mathematical and statistical methods and algorithms to be used in the creation of tools for the identification of unusual money laundering operations. Studies are of analytical, exact nature.

A valuable resource for assessing the state of peak research into unusual business operations, money laundering can be found in an article by Mei and Gao (2014). Based on information from the Web of Science database which includes both scientific articles on the legalization of crime revenue and anti-terrorist financing, Mei and Gao (2014). Analyzed the years 1993 - 2013. Altogether, 891 contributions from the analyzed area were published and included in the Web of Science database. There are around 200 contributions dealing with years 2014 - 2015. It can therefore be stated that the scientific community's interest in this issue is rising, perhaps also due to the alarming increase in money laundering and terrorist financing.

Mei and Gao report (2014) presents the state of development and focus of international money laundering research, based on an analysis of the distribution of authors, distribution organizations, quoted journals, and keywords.

The analysis of Mei and Gao (2014) shows that there are three main ways of investigating money laundering. These areas are as follows:

- Research on the prediction of money laundering offenses;

- Research into legislation against the legalization of criminal proceeds;

- Research into the risk of money laundering in Germany.

The country leading in the number of articles on legalization of criminal proceeds (in the WoS database) is USA with nearly one hundred contributions. It is followed by China, England, Germany and Australia. Romania is ranked sixth. The ten most productive countries in money laundering research are included in the following table.

Table 1 The most productive countries in money laundering research (1993-2013)

\begin{tabular}{|l|l|l|l|}
\hline Country & Number of Contributions & Country & Number of Contributions \\
\hline US & 97 & Romania & 17 \\
\hline China & 42 & Canada & 14 \\
\hline England & 39 & Netherlands & 13 \\
\hline Germany & 21 & Italy & 10 \\
\hline Australia & Ukraine & 10 \\
\hline
\end{tabular}

Source: Mei a Gao (2014)

Among the authors, Hetzer maintains the key position in the world's AML research and plays the most important role (Hetzer 1999a, Hetzer 1999b, Hetzer 2001a, Hetzer 2001b, Hetzer 2003). Also, other authors such as Dongming Xu Shijia Gao, Ping Song, Pengzhou Zhang, Agus Sudjianto, Pieth M., (1994), Thomas Naylor, JC Sharman, and Jun Tang have a far-reaching impact on the development of scientific knowledge in the fight against money laundering. Co-authorship usually exists in teams of D.D. Lin and R. Xue; Bin Feng, Ping Song \& Yang Qifeng; Shijia Gao and Dongming Xu; Agus Sudjianto, Caroline Ziemkiewicz and Alvin Lee; and Oana Andreea Pirnuta, Alina Adriana Arzén, Cosmina Oana Draghici and Gabriel Florin Moisescu. However, there is a lack of interdisciplinarity between cooperation bodies, which may be a limiting factor in further development of 
international money laundering research. Countries around the globe have regulated their own regime of anti money laudering laws to curb and prevent this crime (Ahmad 2017, Blanaru 2013, Hernandez 2009).

Table 2 contains the twelve most productive research institutions involved in combating the legalization of criminal proceeds. We can see them as centers of excellence in scientific research associated with combating money laundering and identifying unusual business operations.

Table 2 Centers of Excellence Research Associated with AML

\begin{tabular}{|c|c|c|}
\hline Institution & Description & $\begin{array}{l}\text { Number of } \\
\text { articles Web } \\
\text { of Science }\end{array}$ \\
\hline $\begin{array}{l}\text { Wuhan University of Technology } \\
\text { http://english.whut.edu.cn/ }\end{array}$ & $\begin{array}{l}\text { Public research university in Wuhan, capital of Hubei } \\
\text { province, China. }\end{array}$ & 7 \\
\hline $\begin{array}{l}\text { Cardiff University } \\
\text { www.cardiff.ac.uk/ }\end{array}$ & $\begin{array}{l}\text { One of the top } 5 \text { UK universities with an excellent } \\
\text { research base. }\end{array}$ & 5 \\
\hline $\begin{array}{l}\text { Queensland University of Technology } \\
\text { https://www.qut.edu.au/ }\end{array}$ & Public research university in Australia & 5 \\
\hline $\begin{array}{l}\text { University of London } \\
\text { www.london.ac.uk/ }\end{array}$ & & 5 \\
\hline $\begin{array}{l}\text { Florida International University } \\
\text { www.fiu.edu/ }\end{array}$ & Public research university in US & 4 \\
\hline $\begin{array}{l}\text { University College Dublin } \\
\text { www.ucd.ie/ }\end{array}$ & Leading research university & 4 \\
\hline $\begin{array}{l}\text { McGill University } \\
\text { https://www.mcgill.ca/ }\end{array}$ & $\begin{array}{l}\text { Canadian public research university based in Montreal, } \\
\text { Quebec }\end{array}$ & 4 \\
\hline $\begin{array}{l}\text { Griffith University } \\
\text { https://www.griffith.edu.au/ }\end{array}$ & Public research university & 4 \\
\hline $\begin{array}{l}\text { Bank of America } \\
\text { https://www.bankofamerica.com/ }\end{array}$ & $\begin{array}{l}\text { Bank of America is the largest US commercial bank in } \\
\text { terms of deposits and the largest company of its kind } \\
\text { in the world. Bank of America is the largest US } \\
\text { company which is not part of the Dow Jones Industrial } \\
\text { Average. }\end{array}$ & 3 \\
\hline $\begin{array}{l}\text { Carnegie Mellon University } \\
\text { www.cmu.edu/ }\end{array}$ & $\begin{array}{l}\text { Research university known by interdisciplinary } \\
\text { programs }\end{array}$ & 3 \\
\hline $\begin{array}{l}\text { The University of Virginia } \\
\text { www.virginia.edu/ }\end{array}$ & Flagship research university & 3 \\
\hline $\begin{array}{l}\text { Southwest Jiaotong University } \\
\text { english.swjtu.edu.cn/ }\end{array}$ & $\begin{array}{l}\text { National Key University in Chengdu, Sichuan, } \\
\text { affiliated with the Ministry of Education of China }\end{array}$ & 2 \\
\hline
\end{tabular}

Source: own processing according to Mei and Gao (2014)

"Journal of Money Laundering Control" is the only periodical in the world specialized in the field of money laundering research. Other major but not monothematic magazines on money laundering include "Crime, Law and Social Change", part of "Lecture Notes in Computer Science", "American Criminal Law Review" and "International Organization". "The Journal of Financial Crime" and "Communications of the ACM", "Pacific Law Journal", "Foreign Affairs", and the "British Journal of Criminology" have a great impact on money laundering research. Interesting magazine is "Journal of Security and Sustainability Issues" - a peer-reviewed journal which publishes original research papers which focused for example in: Conceptual Approaches towards Security, Security Technologies, Technological Development for Security, Computer and Information Security and others. 


\section{ENTREPRENEURSHIP AND SUSTAINABILITY ISSUES}

ISSN 2345-0282 (online) http://jssidoi.org/jesi/

2019 Volume 6 Number 3 (March)

http://doi.org/10.9770/jesi.2019.6.3(15)

Table 3 Summary of the most frequent keywords in articles associated with AML

\begin{tabular}{|c|c|c|c|}
\hline Frequency & Key word & Frequency & Key word \\
\hline 66 & Money laundering & 6 & Fraud detection \\
\hline 22 & Terrorism & 6 & Terrorism financing \\
\hline 19 & Anti - money laundering & 5 & Security \\
\hline 11 & Crime & 5 & Electronic cash \\
\hline 11 & Data mining & 5 & Enforcement \\
\hline 9 & Politics & 4 & Compliance \\
\hline 9 & Corruption & 4 & Risk \\
\hline 8 & Globalization & 4 & Networks \\
\hline 6 & Shadow economy & 4 & Classification \\
\hline 6 & State & 3 & \\
\hline
\end{tabular}

Source: Mei a Gao (2014)

The following overview contains the six most quoted works from the AML area. Based on the number of citations, we can see that this is not an area with a high number of citations (hundreds of quotes as in the case of key publications in the field of economic or medical science). This is mainly due to the need to continuously innovate AML detection procedures.

Truman, E.M. (2014): Chasing Dirty Money: The Fight Again Money Laundering (27 citations)

Strafer, G.R. (1989): Money Laundering: The Crime of the 90s (23 citations)

Irvine, M.R. (1987) Money Laundering Control Act Of 1986: Tainted Money and The Criminal Defence Lawyer (20 citations)

Harmon, J.R. And James, D. (1988): United States Money Laundering Laws: International Implications (18 citations)

Stessens, G. (2000): Money Laundering: A New International Law Enforcement Model (14 citations)

Razzano, F.C. (1994) American Money Laundering Statutes: The Case for A Worldwide System of Banking Compliance Programs (14 citations)

\section{Conclusions}

In order to combat the introduction of criminal proceeds in the legal financial system effectively, it is necessary to improve security and strengthen scientific research capacities in university environment as well as to develop scientific methods that serve the basis for creating software which will allow systematic security and detection of unusual business operations.

Regarding the up-to-date and global manner of unusual business operations, money laundering and protection against legalization of proceeds from crime and protection against terrorist financing, legal and legislative frameworks need to be updated.

Following the legislative frameworks mentioned in the introductory section, an amendment to Act 297/2008 of codex from 2 July 2008 is being prepared on protection against the legalization of proceeds of crime, and prevention of financing of terrorism including amendments to certain laws.

The main purpose of the proposed amendment is the transposition of Directive 2015/849 of the European Parliament and Council of 20 May 2015 on the prevention of the use of the financial system for the purpose of money laundering or terrorist financing, which amends the Regulation 648/2012 of the European Parliament and Council and repeals the Directive 2005/60 / EC of the European Parliament and Council as well as the Commission Directive 2006/70 / EC (hereinafter referred to as "IV AML Directive"). 


\section{ENTREPRENEURSHIP AND SUSTAINABILITY ISSUES}

ISSN 2345-0282 (online) http://jssidoi.org/jesi/

2019 Volume 6 Number 3 (March)

http://doi.org/10.9770/jesi.2019.6.3(15)

The purpose of transposition of IV. AML Directive is particularly to amend the basic requirements of the socalled customer due diligence, or enhanced customer due diligence, namely, the conditions of customer care (basic, simplified and increased).

Uniformity of AML laws among different countries may deter criminals from laundering money. The ratification of the Vienna Convention can help to facilitate uniformity of legal rules. States need robust domestic laws to tackle money laundering. Money laundering is an international crime, although not always a specific crime in international law. Moreover, it is generally advantageous to consider money laundering to be a specific crime under international law (Keesoony 2016).

\section{References}

Ahmad, K; Nasir, A; \& Mohamed, Z.M. 2017. Money Laundering in Malaysia: An Analysis of Court Cases, Asian Journal of Accounting and Governance, 8: 145-152 https://doi.org/10.17576/AJAG-2017-08SI-13

Blanaru, C.A. 2013. Money Laudering by Means of Modern Financial Products and Services. Metalurgia International, 18(1) : 105-107

Dobrovič, J.; Gombár, M.; \& Benková, E. (2017). Sustainable development activities aimed at combating tax evasion in Slovakia. Journal of Security and Sustainability Issues, 6(4): 761-772. https://doi.org/10.9770/jssi.2017.6.4(19)

Durkalić, D. 2016. Impact of trade openness on economic development: case from Serbia. Acta Oeconomica Universitatis Selye 5 (2): 79 87. ISSN 1338-6581

Gródek-Szostak, Z.; \& Nesterak, J. 2017. Trade missions as the instrument for supporting international technological cooperation of enterprises - case study of Poland, Slovakia and Czech Republic. Acta Oeconomica Universitatis Selye 6(2): 57 - 68. ISSN 1338-6581

Hetzer, W. 1999a. Economics and Crime_Law Enforcement Considerations on Business and Criminal Activity. Kriminalistik, 53: 570578.

Hetzer, W. 1999b. European Impulses in Money Laundering_Fighting Tax Evaders and Money. Kriminalistik, 53: 788-793

Hetzer, W. 2001a. Legislative Strategies_Economic Crime and Money Laundering. Kriminalistik, 55: 391-401.

Hetzer, W. 2001b. Organized Crime and Money Laundering-Role of the German BKA in Controlling This Phenomenon. Kriminalistik, 55: $154-156$.

Hetzer, W. 2003. Money Laundering and Financial Markets. European Journal of Crime. Criminal Law and Criminal Justice, 11: $264-277$. http://dx.doi.org/10.1163/157181703322681104

Hernandez, O.V. 2009. Money Laundering: An Economy Between The Ethical and the Technical. Apuntes Del Cenes, 28 (47) : 82-98. Publication of Universidad Pedagógica y Tecnológica de Colombia (UPTC)

Jančíková, E.; \& Veselovská, S. 2018. The new Technologies and the Fight Against Money Laundering and the Terrorism Financing. In 2nd International Scientific Conference - EMAN 2018 - Economics and Management: How to Cope With Disrupted Times, Ljubljana Slovenia, March 22, 2018, ISBN 978-86-80194-11-0. https://doi.org/10.31410/EMAN.2018.334

Jančíková, E.; \& Pásztorová, J. 2018. Strengthened EU Rules to Tackle Money Laundering and Terrorism Financing and their Implementation in Slovak Republic. In Staníčková, M., L. Melecký, E. Kovářová and K. Dvoroková (eds.). Proceedings of the 4 th International Conference on European Integration 2018 . Ostrava: VŠB - Technical University of Ostrava, 2018, pp. 528-536. ISBN 97880-248-4169-4. ISSN 2571-029X.

Keesoony, S. 2016. International anti-money laundering laws: the problems with enforcement. Journal of Money Laundering Control , 19 (2): 130 - 147. https://doi.org/10.1108/JMLC-06-2015-0025 


\section{ENTREPRENEURSHIP AND SUSTAINABILITY ISSUES}

ISSN 2345-0282 (online) http://jssidoi.org/jesi/

2019 Volume 6 Number 3 (March)

http://doi.org/10.9770/jesi.2019.6.3(15)

Korauš, A.; \& Kelemen P. 2018. Protection of persons and property in terms of cybersecurity in Economic. Political and Legal Issues of International Relations 2018. Faculty of International Relations of Univerzity of Economics in Bratislava,1. - 2. juni 2018, Virt, Editor: EKONÓM, 2018, ISBN 978-80-225-4506-8, ISSN 2585-9404

Limba, T.; \& Šidlauskas, A. 2018. Secure personal data administration in the social networks: the case of voluntary sharing of personal data on the Facebook. Entrepreneurship and Sustainability Issues 5(3): 528-541. https://doi.org/10.9770/jesi.2018.5.3(9)

Lorincová, S. 2018. Human resource and corporate culture: Gender-based differences in the assessment. Central European Journal of Labour Law and Personnel Management, 1(1): 28 - 45. https://doi.org/10.33382/cejllpm.2018.01.03

Mamojka, M.; \& Müllerová, J. 2016. New methodology for crisis management RM/RA CRAMM and its legal frame. In: Production management and engineering sciences. - Leiden: CRC Press/Balkema, 2016. pp 185-190. ISBN 978-1-138-02856-2.

Mei, D.X.; Ye, Y.Y.; \& Gao, Z.G. 2014. Literature Review of International Anti-Money Laundering Research: A Scientometrical Perspective. Open Journal of Social Sciences, 2 : 111-120. http://dx.doi.org/10.4236/jss.2014.212016

Meyer, J.; \& Hetzer, W. 1997. Seizing Crime-Derived Assets-Legal and Practical Problems in Controlling Organized Crime. Kriminalistik, $51: 31-36$.

Müllerová, J. 2016. RM/RA CRAMM as a new risk management method for prevention of ecology disasters, 16th International Multidisciplinary Scientific GeoConference SGEM 2016, SGEM2016 Conference Proceedings, June 28 - July 6, Book 5 Vol. 1, pp. 607612. ISBN 978-619-7105-65-0 / ISSN 1314-2704

Müllerová, J.; \& Mamojka, M. 2017. Legal possibilities of the rescue forces during the emergency event. In: SGEM2017 Conference

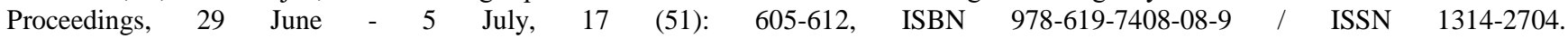
https://doi.org/10.5593/sgem2017/51/S20.079

Mura, L.; Havierniková, K; \& Machová, R. (2017). Empirical results of entrepreneurs' network: Case study of Slovakia. Serbian Journal of Management, 12 (1): 121-131 https://doi:10.5937/sjm12-10418

Pálková, M.; Müllerová, J.; Endrizalová E. 2018. Risk management system in Czech Republic. In: SGEM 2018 conference proceedings. 30 June - 9 July 2018 Albena, Bulgaria [print]. Sofia: STEF92 Technology 18(5.2), pp. 1049-1056. ISSN 1314-2704/ISBN 978-619$7408-47-8$.

Pieth, M. 1994. Tracking Down Ill-Gotten Gains - Combating Money Laudering at an International Level, Conference: Seminar on Crime, with Special Emphasis on Illegal Gains Location: Polizei Fuhrungsakademie, Munster, Germany, Kriminalistik, 48(7) : 442

Šišulák, S. 2017. Userfocus - tool for criminality control of social networks at both the local and international level. Entrepreneurship and Sustainability Issues 5(2): 297-314. https://doi.org/10.9770/jesi.2017.5.2(10)

Veselovská, S.; Korauš, A.; \& Polák, J. 2018. Money Laundering and Legalization of Proceeds of Criminal Activity. In Second International Scientific Conference on Economics and Management - EMAN 2018, March 22, Ljubljana, Slovenia, Printed by: All in One Print Center, Belgrade, 2018, ISBN 978-86-80194-11-0 https://doi.org/10.31410/EMAN.2018

Zulova, J., Svec, M., \& Madlenak, A. (2018). Personality aspects of the employee and their exploration from the GDPR perspective. http://doi.org/10.33382/cejllpm.2018.01.05, 1(1): 68 - 77. http://doi.org/10.33382/cejllpm.2018.01.05 


\section{ENTREPRENEURSHIP AND SUSTAINABILITY ISSUES}

ISSN 2345-0282 (online) http://jssidoi.org/jesi/

2019 Volume 6 Number 3 (March)

http://doi.org/10.9770/jesi.2019.6.3(15)

Short biographical note about the contributors at the end of the article (name, surname, academic title and scientific degree, duties, research interests):

Ass.prof.Ing. Antonín KORAUŠ, PhD., LL.M., MBA is an associate professor at Academy of the Police Force in Bratislava, Slovak republic. Research interests: economy security, finance security, cyber security, energy security, finance, banking, management, AML, economy frauds, financial frauds, marketing, sustainability.

ORCID ID: https://orcid.org/0000-0003-2384-9106

Ass.Prof. Ing. Ján DOBROVIČ, PhD, is an associate professor in the Department of Management, Faculty of Management at the University of Prešov in Prešov since 2006. Since 2013, he works as head of the Department of Management, and he teaches school subjects: Management, Operations Management, Logistics. From 1996 to 2001 he was appointed Regional Director of the Slovak Trade Inspectionin the Prešov Region Prešov. Between 2001-2005 he became the municipal office in Prešov. Between 2006 - 2010 he held the

position of Deputy for International Relations, Director General of the Slovak Tax Directorate. He is also involved in public offices as a member of the city council and deputy Prešov Self-Governing Region.

ORCID ID: https://orcid.org/0000-0002-0637-106X

Ing. Jozef POLÁK, Ph. D. Candidate at the Faculty of Management at the University of Prešov in Prešov, Slovak republic ORCID ID: https://orcid.org/0000-0003-4733-0851

Mgr. Pavel KELEMEN, Ph. D. Candidate at the Faculty of Management at the University of Prešov in Prešov, Slovak republic

ORCID ID: https://orcid.org/0000-0001-7563-3142 